\title{
En psykolingvistisk test til kvantifice- ring af progression i indlæringen af italiensk som fremmedsprog: metoder og resultater
}

\author{
Alexandra Regina Kratschmer, \\ Ocke-Schwen Bohn, Giulia Pierucci, \\ Jocelyn B. Hardman \& Diego Gavagna ${ }^{1}$
}

This article describes a psycholinguistic protocol designed to elicit individual differences in performance regarding phonological (sound discrimination) and lexical (vocabulary memorization) aspects of learning Italian as a foreign language. An experiment built on that protocol revealed a wide range among participants regarding the number of novel vocabulary items memorized as well as a minor spread regarding the discrimination of a novel Italian consonant contrast. No correlation could be revealed between learning success in vocabulary acquisition and phonological discrimination. We conclude that the two types of tasks can be used as instruments for quantifying aspects of learning Italian as a foreign language.

Nøgleord: fremmedsprogsindlæring, gloseindlæring, lyddistinktion, kvantificering af individuelle forskelle, psykolingvistisk forsøg

\section{Indledning: Fremmedsprogstilegnelse - nogle kognitive faktorer}

De resultater, der opnås ved fremmedsprogsindlæring, er afhængige af en lang række henholdsvis eksterne og interne faktorer i forhold til den lærende.

1 Følgende af forfatterne har samarbejdet om følgende dele af eksperimentet: stimulifremstilling og -testning: AK, OSB, GP, DG; gennemførelse af det konkrete forsøg: DG; analyse af lyddata: AK; statistik: JBH, OSB. 
De eksterne faktorer vedrører arten af kontakt med det sprog, der skal læres, samt visse aspekter af undervisningen såsom klassesituation, læringsmaterialer, didaktiske processer og tilgange.

På den anden side vil læringsudfaldene uundgåeligt blive noget forskellige fra elev til elev i en gruppe, også selv om de nævnte eksterne faktorer er ens for alle. Disse individuelle variationer er emnet for den såkaldte differentialpsykologi (eng.: individual differences psychology (PDI)), som koncentrerer sig om den menneskelige adfærds variabilitet i modsætning til de træk, der normalt er fælles. Blandt de interne eller individuelle faktorer, som har indflydelse på tilegnelsen af fremmedsprog, finder man den såkaldte language learning aptitude - et menneskes evner (egnethed, talent) for sproglæring (Dörnyei 2006: 42, 46, 48ff). Der er udarbejdet test, som sigter på at gøre disse evner målbare (se diskussionerne hos f.eks. Dörnyei (2006: 46 ff) eller Grigorenko (2000: 390392)), men vi er ikke stødt på litteratur, som direkte refererer til paradigmer udarbejdet med sigte på kompatibilitet med kravene til en undersøgelse af de neurologiske korrelater til den kvantificerede sproglæringsevne, som i vores tilfælde (se længere nede).

Denne egnethed eller evne til sprogindlæring beskrives som en kombination af følgende kognitive funktioner: evnen til fonetisk kodering ("ability to identify distinct sounds, to form associations between these sounds and the symbols representing them, and to retain these associations"); grammatisk sensitivitet ("ability to recognize the grammatical functions of words (or other linguistic entities) in sentence structures"); evnen til at memorere ("ability to learn associations between sounds and meaning rapidly and efficiently, and to retain these associations"); samt evnen til induktiv sproglæring ("ability to infer or induce the rules governing a set of language materials, given samples of language materials that permit such inferences"). Definitionerne stammer fra Carroll (1981) og citeres i Dörnyei (2006: 46f). Den nyeste forskning på området påpeger ikke blot disse individuelle faktorers kontekstafhængighed, men også de gensidige relationer imellem dem.

Idet alle disse funktioner er kognitive og noget derudover tyder på, at individuelle forskelle angående kognitive funktioner generelt korrelerer med bestemte hjerneaktivitetsmønstre (se f.eks. Klimesch 1999; Haarmann 2005), besluttede vi at undersøge disse sammenhænge i forbindelse med indlæring af italiensk som fremmedsprog i rammen af et to-trins-projekt. Det første trin, som beskrives her, skulle vise, at man indirekte kunne måle forskelle angående de omtalte kognitive funktioner via at kvantificere forsøgspersoners indlæringssucces, og derudover måle, hvorvidt nogle af disse funktioner stod 
i relation til hinanden. Det andet trin, udført ved hjælp af elektroencefalografiske (EEG) målinger, skulle kortlægge, hvorvidt personers individuelle, målte indlæringssucces korrelerede med bestemte hjerneaktivitetsmønstre. I bedste fald kan disse indsigter bruges til på længere sigt at tilbyde personer med ringere indlæringssucces målrettet kognitiv træning, der kan forbedre deres indlæringskapacitet.

Vi valgte i første omgang at fokusere på to af de ovennævnte funktioner, nemlig fonetisk kodering og memorering, idet disse kan siges at være forudsætninger for de to andre. Gloseindlæring kan ikke ske uden lyddistinktion og alle grammatikrelaterede processer bygger på glosernes manipulation (rækkefølge, bøjning). Vi udformede således en test for læringskapacitet, som både rummede en opgave indenfor genkendelse af talelyde og én angående glosememorering. Angående glosememoringen var opgaverne i den første, rent psykolingvistiske, eksperimentdel og den efterfølgende neurolingvistiske del ens, mens lydgenkendelsen var dækket af et aktivt paradigme (se nedenfor) i første del og en helt passiv lytteopgave i anden del. Derfor er ordmemoreringsopaverne også udformet således, at de egner sig til at blive undersøgt med henblik på i EEG-forskningen veletablerede sammenhænge mellem bestemte typer stimuli (sprogligt input) og hjernens reaktionsmønstre.

Vores konkrete mål med eksperimentet var på den ene side at kunne påvise, at det af os udarbejdede indlæringsparadigme var i stand til at elicitere en naturlig og tydelig spredning forsøgspersonerne imellem angående deres indlæringssucces, og på den anden side tillade en kortlægning af en eventuel korrelation mellem evnen til at memorer og evnen til at genkende fremmedsproglige lyde.

I det følgende vil vi præsentere resultaterne af vores første eksperimentdel, som er gennemført ved afdelingen for Italiensk ved Aarhus Universitet med 30 dansktalende personer uden forudgående kendskab til italiensk sprog, i perioden februar til april 2013. Projektet er finansieret af Aarhus Universitet via AU Ideas Project Startup Grant.

\section{Eksperiment om laringskapacitet i italiensk som fremmedsprog}

\subsection{Forsøgspersonerne}

36 raske deltagere (20 kvinder, 16 mænd) i alderen fra 19 til 33 år (gennemsnit: 25,5 år) - alle nuværende eller tidligere universitetsstuderende, blev rekrutteret 
gennem fysiske og elektroniske opslag og personlige kontakter. Vi medtog kun ensprogede ${ }^{2}$ danskere uden forudgående kendskab til det italienske sprog. Efter eksperimentet udfyldte forsøgspersonerne et spørgeskema om deres sociokulturelle baggrund, hvori der indgik spørgsmål om deres kendskab til andre fremmedsprog og om deres personlige vurdering af egne evner og lyst til fremmedsprogslæring.

Alle forsøgspersonerne modtog som tak en biografbillet til en værdi af 75 kroner (10 euro).

Det bør bemærkes, at den elektroniske gennemførelse af ordlæringsopgaven for de første 6 forsøgspersoners vedkommende (3 mænd og 3 kvinder) ikke forløb korrekt, og de respektive data derfor er trukket ud af analysen. Hvad angår lyddistinktionsopgaven, er alle 36 datasæt dog analyseret, men i sammenligningen af resultaterne fra henholdsvis ordopgaven og lydopgaven indgår kun de sidste 30 datasæt.

\subsection{Metode}

\subsubsection{Distinktion mellem talelyde}

\subsubsection{Opgavens udformning}

Evnen til at skelne mellem talelyde blev målt ved hjælp af et eksperiment over paradigmet "AXB". Metoden består i gennem høretelefoner at præsentere tre særskilte talelyde efter hinanden og bede forsøgspersonerne om at afgøre, om den midterste ("X") "er lig med" den først præsenterede ("A") eller den sidst præsenterede ("B"). For forsøgspersonen drejer det sig altså om at kunne kategorisere de præsenterede talelyde i henhold til deres akustiske egenskaber. Svaret skulle afgives ved at klikke med en computermus på én af to firkanter på en computerskærm. Firkanterne bar tallene henholdsvis " 1 " eller "3" svarende til den første eller den tredje lyd i rækken, som den midterste lyd skulle sammenlignes med.

I dette paradigme, som her var baseret på stavelsespar, der samtidig var minimalpar, drejede det sig om at afgøre, om den stavelse, der blev præsenteret som nummer to, var af typen /li/ (en fonotaktisk kombination, som optræder både i dansk og italiensk) eller af typen / $\mathrm{K}$ / (som ikke forekommer som fonem i dansk, men bruges i italiensk ${ }^{3}$ ). Begge stavelser kunne forekomme i såvel position $\mathrm{A}$ som position $\mathrm{B}$, men ikke i begge positioner i samme triplet

2 Dvs. med udelukkende dansk som modersmål, med øvrige sprog tillært som fremmedsprog.

3 Det findes i dansk dog som et medialt allofon af $/ \mathrm{l} /$ foran $/ \mathrm{j} /$. 


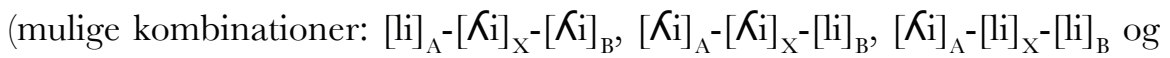
$\left.[\mathrm{ii}]_{\mathrm{A}}-[\mathrm{ii}]_{\mathrm{X}}-[\mathrm{Ki}]_{\mathrm{B}}\right)$.

I alt blev forsøgspersonerne præsenteret for 96 tripletter i løbet af ca. 12 minutter. Forud for selve eksperimentet øvede forsøgspersonerne sig i at udføre en opgave af samme type med stavelserne /pu/ og /bu/, som er lette at skelne fra hinanden for et dansk øre, indtil deltagerne gav udtryk for at have forstået proceduren.

\subsubsection{Stimuli af typen $A X B$}

Fra et korpus af forskellige stavelser, som hver for sig blev præsenteret skriftligt tyve gange i tilfældig orden til en italiensktalende person, oplæst af sidstnævnte og lydoptaget, blev der valgt 6 repræsentanter for hver stavelsestype på grundlag af artikulationens klarhed og prototypiske karakter. De udvalgte lydoptagelser blev derpå konverteret fra stereo til mono og normaliseret med henblik på ensartet lydstyrke.

Som piloteksperiment udvalgte vi på grundlag af udtalens vanskelighed for dansktalende følgende minimale stavelsespar, som en indfødt italiener derpå indtalte på et lydmedium: /tse/ vs. /dze/, / $\int_{\varepsilon} /$ vs. $/ \mathrm{d}_{3} \varepsilon /, / \mathrm{d} 3 \varepsilon / \mathrm{vs} . / \mathrm{dz} \varepsilon /$, /li/ vs. / Ki/, /ni/ vs. / $\mathrm{ni} /$ og / Ki/ vs. / $\mathrm{Ni} /$. Alle stavelserne blev afprøvet på andre indfødte italiensktalende over 24 runder AXB, og deres fejlfrie resultater viste, at de havde let ved at skelne imellem dem. Efterfølgende blev 4 danske forsøgspersoner præsenteret for AXB-prøver i 24 runder med disse 6 minimale par. Kun ét af de minimale par førte til et relevant antal kategoriseringsfejl, nemlig /li/ over for / $\mathrm{Ki}$ /. I dette tilfælde var fejlmønstrene interessante, fordi de viste sig at være specielt egnede til at skelne mellem hurtige og mindre hurtige lærende. 1 af de 4 forsøgspersoner i pilotstudiet begik ingen fejl, mens 2 forsøgspersoner begik nogle fejl (henholdsvis 2 og 4), kun eller overvejende i begyndelsen. Den sidste forsøgsperson begik 7 fejl fordelt over hele piloteksperimentet. Vi vurderede efterfølgende, at disse tre fejlmønstre potentielt kunne bruges som indikation af henholdsvis forud eksisterende lyddistinktionsevne, evne til hurtig indlæring eller mangel på samme. På grundlag af disse observationer valgte vi derpå parret /li/ over for / Ki / som grundlag for AXB-testen i det endelige eksperiment.

\subsubsection{Ordlering}

Til at måle ordtilegnelsen har vi valgt metoden paired associates (Mårtensson/ Löwdén 2011), hvor vi har forbundet danske ord med italienske pseudoord - 
ord, som overholder de fonotaktiske regler for italiensk, men hvortil der ikke svarer noget semantisk indhold, f.eks. svaccia, loddo, ubbo). Dette valg traf vi for at undgå, at forsøgspersonernes eventuelt eksisterende individuelle ordforråd skulle skævvride dataene. For at undgå eventuelle systematiske associationer mellem enkelte danske og pseudoitalienske ord (og dermed uforholdsvis nem indlæring) satte vi pseudoord og danske ord sammen på en ny, randomiseret måde for hver enkelt deltager.

\subsubsection{Presentation og eliciteret adferd}

For at undgå sammenblandingseffekter ved læsning og skrivning i tilfælde af dysleksi og lignende har vi udelukkende benyttet stimuli i lydform. Alle instrukser forud for hver enkelt testrunde blev ligeledes præsenteret i lydform og var indtalt af en dansksproget mand, mens alle stimuli (danske og pseudoitalienske ord) var indtalt af henholdsvis en dansk og en italiensk kvinde. Den adfærd, deltagerne blev tilskyndet til, bestod - alt efter opgaven - i at lytte opmærksomt (memoreringsfasen), at trykke på en knap på et lille apparat for at angive korrekthed eller ukorrekthed (genkendelsesfasen) og endelig at artikulere ordet foran en mikrofon, der optog resultatet elektronisk (produktionsfasen).

\subsubsection{Generelt design for ordmemoreringsopgaven}

Eksperimentet var opdelt i tre runder med samme interne struktur, hvilket gav mulighed for gentagelse af de enkelte opgavetyper og dermed mulighed for en dokumenterbar læringskurve hos forsøgspersonerne fra runde til runde. Hver runde omfattede en memoreringsfase, en genkendelsesopgave og en produktionsopgave. I alle opgaverne blev der arbejdet med den samme liste på 40 dansk-pseudoitalienske ordpar. Memoreringsfasen var baseret på en præsentation af de 40 lydindspillede ordpar, kombineret forskelligt fra person til person, i randomiseret orden, som til og med varierede fra runde til runde for at undgå en skæv indlæring af listen (fx ved at forsøgspersonen udelukkende koncentrerede sig om de første ord på listen). Genkendelsesopgaven bestod i præsentation af 80 dansk-pseudoitalienske ordpar, heraf 40 "korrekte" (dvs. i overensstemmelse med sammenkoblingen fra memoreringsopgaven) og 40 "ukorrekte" (dvs. som ikke respekterede denne sammenkobling), i tilfældig orden, igen forskellig fra runde til runde. Forsøgspersonerne blev instrueret i at trykke på en knap for "rigtigt" eller en anden knap for "forkert" i henhold til hver enkelts egen vurdering af det pågældende ordpars (u)overensstemmelse med de tidligere præsenterede ordpar. Computerskærmen gengav ikonisk de respektive knappers farve og placering på apparatet sammen med ordene "rig- 
tigt" og "forkert". Forsøgspersonerne havde 2 sekunder til at svare, hvorefter et nyt ordpar blev præsenteret. Svarene og tilhørende reaktionstider (under 2 sekunder) blev registreret. Både forsinkede og udeblevne svar blev registreret som ukorrekte. Produktionsopgaven bestod i akustisk præsentation af de 40 danske ord ét for ét samt instruks om at udtale det tilsvarende pseudoitalienske ord efter en klartone. Svarene blev optaget ved hjælp af en mikrofon. Til de tre runder havde forsøgspersonerne $\mathrm{i}$ alt lidt under en time til rådighed.

Forud for eksperimentets begyndelse blev de tre opgavetyper samt udstyrets funktioner forklaret for forsøgspersonerne. For at undgå, at forsøgspersonerne benyttede computertasturet mnemoteknisk (som det var sket under piloteksperimenterne), var det under hele eksperimentet dækket af et stykke stof. For at undgå tvivl hos forsøgspersonerne angående de "italienske" ords ægthed forklarede man desuden, at det drejede sig om ord fra en italiensk dialekt, som var valgt, netop fordi dens leksikon ikke havde etymologiske rødder til fælles med standarditalienske ord.

\subsubsection{Stimuli}

\subsection{Danske stimuli}

Der blev valgt 80 danske substantiver, som blev fordelt ligeligt på to lister. Substantiverne blev valgt blandt de mest frekvente (ud fra Korpus 2000, ved Asmussen et al., (2002)). Det skulle være tællelige enstavelsesord med konkret denotation, og vi undgik homonymer ("kort"), homofoner ("hjul" / "jul"), professions- og sociale rolleangivelser ("kok", "mor") og desuden nogle ord, som senere viste sig ikke at være akustisk entydige i en transskriptionstest med dansktalende (fx "torv", som gentagne gange blev blandet sammen med både "tåre" og "tov".). De to lister blev fordelt på forsøgspersonerne efter deltagernumre (henholdsvis lige og ulige numre).

De præliminære ordlister blev læst højt af en dansktalende person og indtalt på et lydmedie. Der blev derefter valgt en repræsentant for hvert ord på grundlag af artikulationen, som både skulle være klar og prototypisk.

De udvalgte og indtalte ord blev derpå konverteret fra stereo til mono og normaliseret med hensyn til lydstyrke.

\subsection{Pseudoitalienske stimuli}

Pseudoordene er konstrueret, så de respekterer både lingvistiske og - med henblik på efterfølgende brug i en neurolingvistisk undersøgelse - også krav fra sidstnævnte disciplin (fx absolut ensartethed i lydstyrke)).

Fra et fremmedsprogsindlæringssynspunkt findes der visse fonotaktiske 
forbindelser, som notorisk giver problemer for danske italienskstuderende (i hvert fald produktionsmæssigt, ikke nødvendigvis perceptionsmæssigt). Hertil hører stemte klusiler (/b/, /d/, /g/), affrikater (ustemte: /ts/, /t $\int /$ og stemte: /dz/ og /dz/) samt stemte og ustemte geminerede klusiler og affrikater: /b:/, /d:/, /g:/, /p:/, /t:/, /k:/, /dz:/, /ts:/, /dz:/, /t $: / /)$, som ikke indgår i det danske fonemsystem. ${ }^{4}$ Alle stimuli blev konstrueret omkring en gemineret konsonant i midten af ordet ( $\mathrm{fx}$ criccio, paggia, ubbo).

De således konstruerede ord var udvalgt blandt pseudoord genereret af et computerprogram, som - med hjælp fra et elektronisk baseret leksikon med frekvensangivelse og stavelsesdeling - kan generere pseudoord til en række sprog: det såkaldte "Wuggy", som er udarbejdet af den belgiske psykolingvist Emmanuel Keuleers og kan findes gratis på nettet (http://crr.ugent.be/programsdata/wouggy, se også Keuleers og Brysbaert (2010)). Ved tilpasning af Wuggy til det italienske sprogsystem er benyttet det syllabiserede italienske leksikon af Goslin et al. 2013 (phonitalia.org), som igen er baseret på Corpus e Lessico di Frequenza dell'Italiano Scritto (CoLFIS) af Bertinetto et al. 2005.

Listen med pseudoord blev efterfølgende udarbejdet efter samme kriterier og procedurer, som er benyttet ved opstillingen af de danske lister (se 2.2.2.3.1.).

Den akustiske naturlighed og entydighed af de fremkomne ord blev derpå verificeret ved en transskriptionstest. Vi bad en række indfødte italiensktalende om at lytte til ordene, transskribere dem og samtidig angive åbningsgraden af vokalerne "e" og "o" samt stemthed/ustemthed af " $z$ " - en opgave, der for vores informanter var fuldstændig uproblematisk.

\subsubsection{Bedommelseskriterier for gloseproduktionsdata}

I betragtning af deltagernes mulige vanskeligheder med at artikulere et memoreret ord korrekt krævedes der forud fastlagte og stringente kriterier til objektiv fastlæggelse af forskellen mellem dårligt memorerede ord på den ene side og velmemorerede men dårligt udtalte ord på den anden. ${ }^{5}$ Det gjaldt i særdeleshed stemthed/ustemthed af den geminerede lyd centralt i ordet. Ud fra den forudsætning, at deltagerne var i stand til at identificere en stemt

4 Indlemningen af fonologiske udfordringer i de gloser, der skal læres, åbner muligheden for at studere interaktionen mellem de to lingvistiske niveauer. De relevante dataer skal dog først analysers.

5 Det skal bemærkes, at forsøgspersonerne blev instrueret om at huske så mange ord som muligt, så nøjagtigt som muligt, men blev ikke i særdeleshed gjort opmærksomme på at skulle fokusere på deres egen udtale, idet vi for dette første forsøg valgte kun at fokusere på én isoleret parameter. Det ville være oplagt i et fremtidigt forsøg at undersøge memorering og korrekt fonetisk tilegnelse som ét komplekst fænomen. 
klusil (f.eks. /d/) centralt i det memorerede ord, regnede vi en dansk, ustemt og aspireret t-lyd [ $\mathrm{t}^{\mathrm{s}}$ ] for en fejl (eftersom de "ustemte" ${ }^{\text {" }}$ klusiler på dansk er aspirerede), mens artikulation af en ustemt, uaspireret klusil blev regnet for korrekt (eftersom "stemte" danske klusiler adskiller sig fra "ustemte" ved fravær af aspiration). På den anden side blev genkendelse af en italiensk ustemt klusil $(/ \mathrm{t} /$ ) regnet for problematisk (eftersom den italienske, uaspirerede, udtale af grafemet " $t$ " af en dansktalende nemt kan blive fortolket som den (hårde) danske udtale af grafemet "d"), og derfor blev både uaspirerede udtaler (svarende til de "stemte" danske talelyde) og aspirerede udtaler (svarende til "ustemte" danske talelyde) regnet for vellykkede. Angående de centrale geminerede lyde i de pseudoitalienske ord, blev hverken fravær af forlænget lukke i klusilen/affrikaten eller fravær af kort forudgående vokal regnet for fejl, med den begrundelse, at det forlængede lukke hverken findes som distinktivt træk i dansk, men heller ikke kunne infereres for det italienske system fra det begrænsede stimulusbatteri (idet alle stimuli indeholdt geminater), hvorfor vi ikke anså genkendelsen af dette som et rimeligt læringsmål for deltagerne. Det samme gjaldt for kortvokal før dobbeltkonsonanter, hvis fonologiske rolle heller ikke kunne infereres udfra stimulusbatteriet. Skønt dette også er det normale i det danske sprogsystem, forekommer kortvokalen på dansk ikke kun i disse forbindelser og bliver derfor af dansktalende ikke automatisk sat i forbindelse med dobbeltkonsonanter (som man kan se af danskeres stavefejl).

Det bør tilføjes, at der ud over de ord, som blev regnet for vellykkede memoreringer, også blev produceret nesten korrekte ord (staggia i stedet for staggio), lignende ord (f.eks. svazza) og fuldstændig ukorrekte ord (f.eks. trutto). Disse fænomener vil dog blive diskuteret i et andet forum.

\section{Resultater og diskussion}

Vi viser først resultaterne for hver enkelt deltager i hver enkelt opgave, udtrykt ved procentdel korrekte svar. Tabel 1 viser procenttallene for lyddistinktionsopgaven ("AXB"), for ordGenkendelsesopgaven ("G1", "G2" og "G3" for de tre runder), samt for ordProduktionsopgaven ("P1", "P2" og "P3" for de tre runder). Som tidligere nævnt findes der for de første 6 forsøgspersoner udelukkende brugbare data for AXB-opgaven.

6 Termerne "stemt" og "ustemt" er sat i anførselstegn her, da de refererer til de danske klusiler, der bliver repræsenteret af grafemerne "d" og " $t$ ", selv om begge er ustemte. 


\begin{tabular}{|c|c|c|c|c|c|c|c|}
\hline Deltager & AXB & Gl & G2 & G3 & P1 & P2 & P3 \\
\hline $\begin{array}{ll}1 \\
2\end{array}$ & $\begin{array}{l}84 \\
86\end{array}$ & & & & & & \\
\hline \begin{tabular}{|l|}
3 \\
4
\end{tabular} & $\begin{array}{l}80 \\
88\end{array}$ & & & & & & \\
\hline 5 & 66 & & & & & & \\
\hline 6 & 82 & & & & & & \\
\hline 7 & 91 & 51 & 68 & 69 & 13 & 13 & 20 \\
\hline 8 & 95 & 61 & 76 & 79 & 13 & 38 & 48 \\
\hline 9 & 94 & 49 & 54 & 66 & 0 & 5 & 15 \\
\hline 10 & 94 & 45 & 62 & 70 & 0 & 3 & 20 \\
\hline 11 & 91 & 28 & 31 & 50 & 0 & 3 & 13 \\
\hline 12 & 97 & 56 & 61 & 90 & 0 & 5 & 8 \\
\hline 13 & 89 & 51 & 76 & 88 & 3 & 13 & 20 \\
\hline 14 & 91 & 69 & 86 & 91 & 5 & 18 & 33 \\
\hline 15 & 86 & 64 & 75 & 91 & 3 & 20 & 30 \\
\hline 16 & 99 & 56 & 81 & 90 & 8 & 33 & 48 \\
\hline 17 & 100 & 59 & 73 & 81 & 5 & 18 & 40 \\
\hline 18 & 96 & 58 & 70 & 93 & 3 & 28 & 33 \\
\hline 19 & 90 & 62 & 86 & 90 & 15 & 23 & 30 \\
\hline 20 & 92 & 49 & 65 & 78 & 5 & 18 & 63 \\
\hline 21 & 96 & 44 & 62 & 56 & 3 & 5 & 5 \\
\hline 22 & 82 & 49 & 59 & 81 & 8 & 28 & 38 \\
\hline 23 & 96 & 49 & 71 & 89 & 0 & 8 & 20 \\
\hline 24 & 99 & 56 & 71 & 73 & 0 & 15 & 25 \\
\hline 25 & 91 & 45 & 69 & 83 & 8 & 28 & 33 \\
\hline 26 & 90 & 51 & 62 & 74 & 3 & 28 & 43 \\
\hline 27 & 96 & 64 & 66 & 86 & 3 & 28 & 43 \\
\hline 28 & 83 & 68 & 85 & 95 & 10 & 18 & 23 \\
\hline 29 & 95 & 46 & 79 & 95 & 8 & 28 & 43 \\
\hline 30 & 98 & 39 & 65 & 69 & 3 & 10 & 15 \\
\hline 31 & 85 & 48 & 65 & 76 & 3 & 8 & 20 \\
\hline 32 & 94 & 50 & 60 & 69 & 0 & 0 & 5 \\
\hline 33 & 99 & 58 & 66 & 81 & 5 & 13 & 20 \\
\hline 34 & 96 & 39 & 65 & 78 & 0 & 3 & 0 \\
\hline 35 & 95 & 35 & 58 & 80 & 5 & 5 & 5 \\
\hline 36 & 99 & 62 & 66 & 83 & 3 & 30 & 38 \\
\hline
\end{tabular}

Tabel 1. Resultater for alle deltagere $i$ alle opgaver: procent korrekte svar.

Af denne tabel ser man, hvordan de forskellige opgaver forekom mere eller mindre vanskelige at udføre korrekt for gruppen af deltagere som helhed. AXB-testen med procenter mellem 66 (deltager 5) og 100 (deltager 17) viste sig at være lettere end ordgenkendelsen, hvor procenten af korrekte svar ligger mellem 50 (deltager 11) og 95 (deltagerne 28 og 29) i tredje runde. Den vanskeligste opgave har vist sig at være produktionsopgaven, hvor procentsatserne ligger mellem 0 (deltager 34) og 63 (deltager 20) i tredje runde.

\subsection{Distinktion mellem talelyde (AXB)}

Det springer i øjnene, at procentsatserne for korrekte svar er temmelig høje. Det er værd at bemærke, at resultatet på $66 \%$ hos deltager 5 er en outlier. Resten af deltagerne har resultater mellem 80 og $100 \%$. Lad os ikke glemme, at kontrasten mellem /li/ og / Ki / i pilottestene - som vi brugte til at afgøre, hvilke lydlige kontraster der ville forekomme vanskelige for deltagerne og 
fremhæve forskellene mellem deres forskellige indlæringssucces med hensyn til lyddistinktion - var den eneste, som gav resultater med et større antal fejl.

Uanset denne kendsgerning viser vores data en signifikant forskel mellem andelen af begåede fejl og den "type" talelyd (eller fonem), der forekommer i triplettens centrale position $(\mathrm{X})$ og som skal identificeres enten med fonemet i initial position (A) eller med det i final position (B). Hvis man ser på alle svar fra alle deltagere $\mathrm{i}$ alle test omfattende stavelsen /li/ i position $\mathrm{X}$, når man frem til $95 \%$ korrekte svar $(\mathrm{SD}=5,8)$, mens tallet falder til $89 \%(\mathrm{SD}=8,6)$ for stavelsen / $\mathrm{i} /$, altså det ukendte fonem $(\mathrm{t}(70)=-3,344, \mathrm{p}>0,01$; se figur 1$)$.

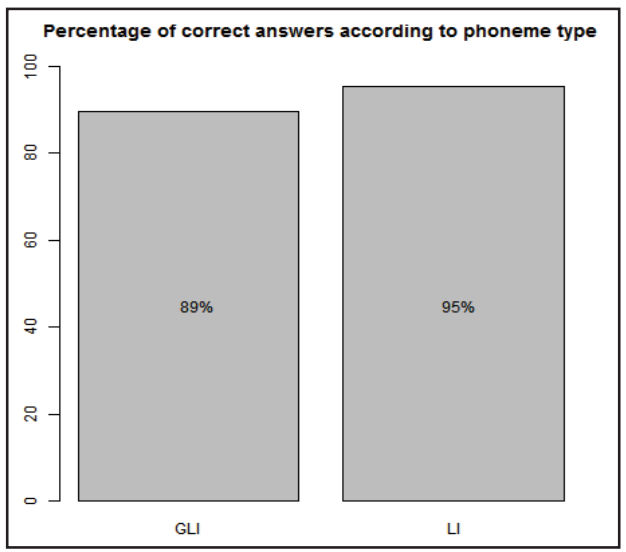

Figur 1. Procent korrekte svar (forsogspersonerne 1-36) for / Ki/ og /li/ i position X i opgaven AXB.

Dette understreger under alle omstændigheder, at den lydkombination, der ikke kendes fra modersmålet ([Ki]), er sværere at genkende og kategorisere end den kendte talelydskombination [ii] - et i og for sig forudsigeligt resultat, også selv om opgavens generelle sværhedsgrad for hovedparten af deltagerne har vist sig at være lavere end forudset.

\subsection{Ordgenkendelse}

Som ovenfor nævnt viste ordgenkendelsesopgaven (klassifikation af par af dansk-pseudoitalienske ord som korrekt eller ukorrekt sammenstillede) sig langt sværere end opgaven i lyddistinktion. Det bør desuden bemærkes, at selve opgavetypen (med to mulige svar: "korrekt" eller "ukorrekt") indebærer en sandsynlighed på $50 \%$ for tilfældigt afgivne, korrekte svar, hvilket begrænser udsvingene i resultaterne. Derfor virker opgaven ved første øjekast mindre egnet til at skelne klart mellem mere og mindre succesrige lærende på baggrund 
af deres resultater. Men som vi senere skal se, bekræfter et overblik over vores data fra produktionsopgaven denne opgavetypes anvendelighed til formålet.

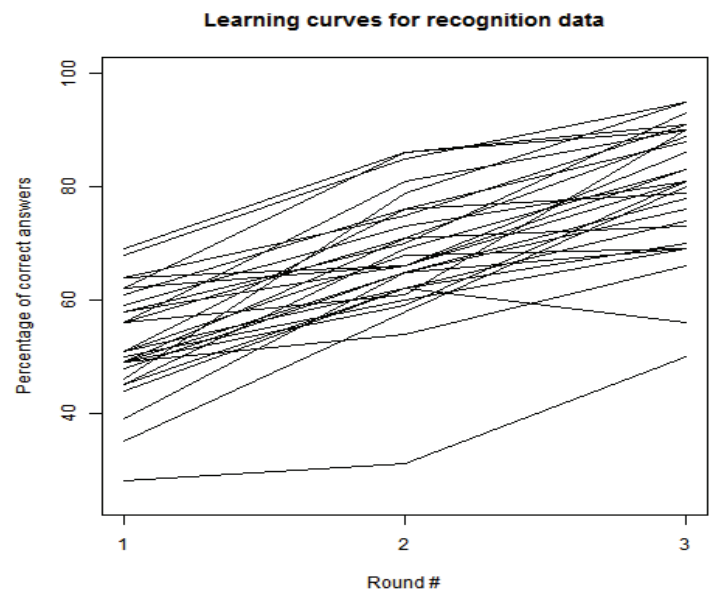

Figur 2. Leringskurver for alle deltagere (7-36) i de tre runder af ordgenkendelsesopgaven.

Det bør også bemærkes, at visse deltagere opnåede resultater, der lå lavere end tilfældighedsniveau, især i de første to runder, hvilket viser, at svarene ikke var automatsvar, men derimod overvejede svar, om end forkerte. Se især resultaterne for forsøgsperson 11 , som opnår $28 \%$ i første runde, $31 \%$ i anden og 50\% (svarende til tilfældige gæt) i tredje.

I figur 2 ser man læringskurverne (fra første over anden til tredje runde) for alle deltagere. Man ser en generel vækst fra runde til runde, og man bemærker, at de enkelte resultatkurver forløber nogenlunde parallelt og ligger ret tæt sammen inden for hver enkelt runde. Der er kun én deltager (nr. 21), hvis resultater falder i sidste runde (fra $62 \%$ i anden til 56\% i tredje runde), sandsynligvis på grund af træthed. Man ser også forsøgsperson 1 l's beskedne resultater som en isoleret kurve i bunden af figuren. I tredje omgang ligger resultaterne som tidligere nævnt mellem $50 \%$ for deltager 11 og $95 \%$ for deltagerne 28 og 29.

\subsection{Ordproduktion}

Denne opgave har ikke bare vist sig at være den vanskeligste - som allerede nævnt med resultater mellem $0 \%$ (deltager 34 ) og $63 \%$ (deltager 20) i tredje runde - men også den mest velegnede til at give en differentieret fremstil- 
ling af præstationsniveauet hos deltagerne (se tabel 4) Læringskurverne for ordproduktion ligger for gruppen som helhed meget mindre tæt end læringskurverne for ordgenkendelse (figur 2), der som vist ovenfor fremstår som et bundt kurver af en vis kompakthed.

Af kurverne ser vi også, at en relativ succes i tredje runde i almindelighed fremstod som et resultat af betydelige fremskridt i to faser (både mellem første og anden runde og mellem anden og tredje, for eksempel deltagerne $16 \mathrm{og}$ 26). Deltagere, som ikke forbedrede deres resultater betydeligt enten mellem første og anden runde (deltager 10), eller mellem anden og tredje runde (deltager 15), er forblevet på et mellemniveau. Forsøgspersoner, som slet ikke har gjort betydelige fremskridt mellem en runde og den følgende, er forblevet på et lavt niveau (f.eks. deltagerne 12 og 21).

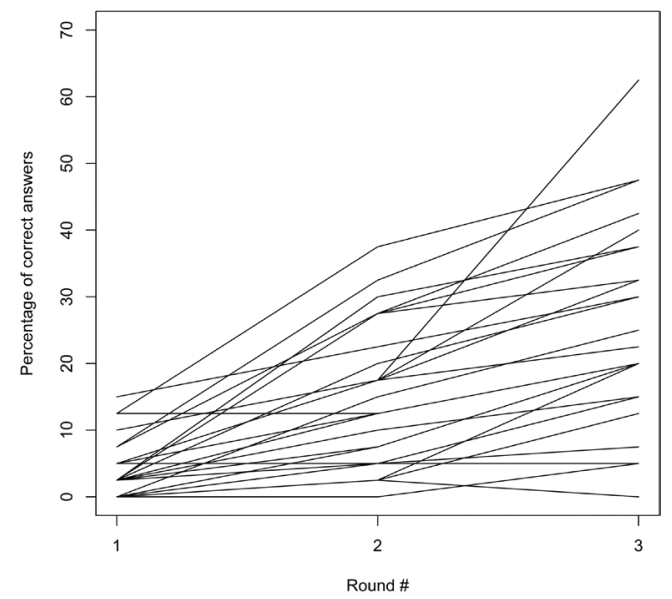

Figur 3. Leringskurver for alle deltagere (7-36) i de tre runder af ordproduktionsopgaven.

Den eneste undtagelse fra denne tendens er deltager 20, hvis spring mellem første og anden runde ikke var specielt udtalt, men som foretog et betydeligt spring mellem anden og tredje runde, hvor vedkommende leverede den bedste af alle præstationer. I figur 3 ser man tydeligt den pågældendes læringskurve, som hæver sig over de andre hen imod slutningen, men ligger i midterområdet i anden runde. I samme tabel ser man deltager 34's læringskurve, der falder fra anden til tredje runde, samt kurverne for deltager $21 \mathrm{og} 35$, der ikke viser fremskridt, og de er alle udtryk for mindre vellykkede resultater. 


\subsection{Korrelationen mellem ordgenkendelse og ordproduktion}

Selv om læringskurverne for hele gruppen af deltagere i de to opgaver ikke fremstår som fuldstændig ensartet fordelt, og selv om det ser ud til at være produktionsopgaven, som bedst får forskelle mellem de enkelte deltageres præstationer frem, er de to opgavers resultater faktisk indbyrdes korrelerede. En beregning af korrelationen product-moment efter Pearson giver en signifikant positiv korrelation $(p=0,02293)$ ved signifikansniveau $0,05(5 \%)$. Korrelationskoefficenten er 0,4140517, en effektstørrelse af middelstyrke; der hersker derfor en vis tendens til, at en deltagers succes eller fiasko i den ene opgave hænger sammen med samme deltagers succes eller fiasko i den anden opgave, hvilket giver mening, da begge opgaver kræver en allerede tilstedeværende fortrolighed med de nye gloser.

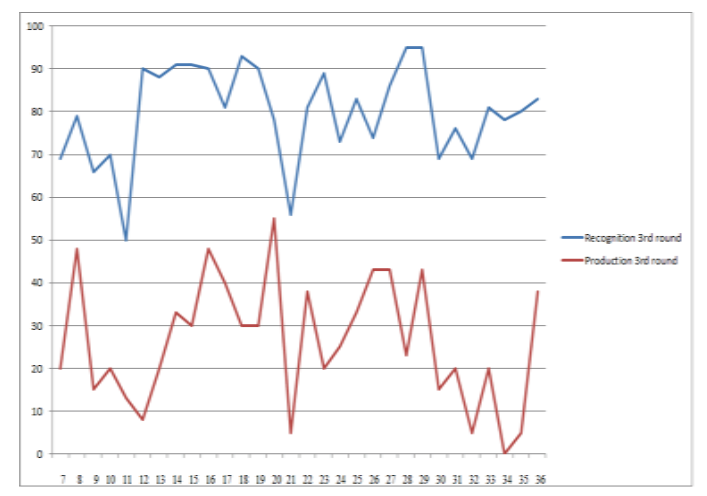

Figur 4. Korrelation mellem resultaterne i tredje runde: genkendelse (ø.) og produktion (n.) for hele gruppen (7-36).

I figur 4 ser vi resultaterne (procent korrekte svar i tredje runde) for hver enkelt af de 30 deltagere (nummer 7 til 36): resultater for ordgenkendelse øverst og resultater for ordproduktion nederst. Man kan se, at resultaterne følges nogenlunde ad.

Udformningen af opgaven i ordgenkendelse har altså vist sig lidt mindre velegnet end ordproduktionsopgaven til at fă nuancerne i læringspræstationerne frem, men den var alligevel i stand til at producere den ønskede spredning.

\subsection{Korrelationen mellem talelydsdifferentiering og memo- rering af ord (genkendelse og produktion)}

Vores undersøgelse har med sin specifikke udformning ikke skaffet evidens for en korrelation mellem på den ene side succes med at skelne mellem en velkendt 
talelyd og en ikke velkendt eller fremmedartet, og på den anden side succes med at indlære fremmedord. En beregning af korrelationen product-moment ifølge Pearson viser, at der ved $5 \%$ signifikansniveau ikke er nogen signifikant relation, hverken mellem AXB og ordgenkendelse eller mellem AXB og ordproduktion (værdien af p er henholdsvis 0,592 og 0,7854).

Det bør bemærkes, at den talelyd, som ikke var velkendt for deltagerne ([Ki]), ikke optrådte i de (pseudo)ord, der skulle memoreres og som alle var opbygget omkring en central gemineret konsonant af typerne klusil eller affrikat (stemt eller ustemt).

Vi kan konkludere, at der for at nå vores mål - nemlig at fremskaffe mere præcise og signifikante data angående korrelationen mellem succes i læring af fremmede talelyde og succes i læring af et fremmedsprogligt vokabular - vil være behov for et mere stringent undersøgelsesdesign.

\section{Konklusion}

I denne artikel har vi analyseret resultaterne af et eksperiment med 30 deltagere på grundlag af et psykolingvistisk paradigme med henblik på at fremkalde kvantificerbare præstationer i relation til fremmedsprogsindlæring. De aspekter af læringen, som indgår i paradigmet, er memorering af nye ord (ordgenkendelse og ordproduktion) samt distinktion mellem delvist nye talelyde.

Især opgaven i ordproduktion (men i mindre grad også opgaven i ordgenkendelse) har afsløret stor variation mellem deltagerne med hensyn til antallet af lærte ord ved afslutningen af læringsforløbet. Det har også været muligt at påvise en middelstærk korrelation mellem succes i den ene og den anden af de to sidstnævnte opgaver. Hvad angår evnen til at skelne mellem talelyde, viste alle præstationerne sig at ligge på relativt højt niveau, omend med individuelle variationer. Det har ikke været muligt at fastslå nogen korrelation mellem succes i ordlæring og succes i lyddistinktion. Vi konkluderer, at de to eksperimenttyper har vist sig velegnede som instrumenter til at kvantificere de to mest grundlæggende aspekter af evnen til læring af det italienske sprog som fremmedsprog, nemlig memorering af ordforråd samt distinktion mellem talelyde, som de grammatikrelaterede sprogindlæringsfunktioner bygger på. Samtidig har paradigmet, som blev udformet med det yderligere mål at skabe et grundlag for en efterfølgende neurolingvistisk undersøgelse med brug af EEG vedrørende en mulig korrelation mellem indlæringssucces og neurofysiologisk aktivitet, vist sig velegnet til dette formål, da paradigmet, udover at kvantificere indlæringssucces, er bygget på stimuli, der opfylder kravene 
til en EEG-undersøgelse. Hvis en EEG-undersøgelse kan vise, at indlæringssuccesen er korreleret med bestemte hjerneaktivitetsmønstre, åbner dette op for muligheden for at udarbejde kognitive træningsprogrammer for personer med ringere indlæringssucces og dermed forbedre deres indlæringskapacitet.

\section{Tak}

$\mathrm{Vi}$ vil gerne takke følgende institutioner og personer for deres bidrag. Uden dem ville det ikke have været muligt at gennemføre projektet i dets nuværende form: AU Ideas Project Startup Grant/Aarhus Universitet, Søren Bo Andersen, Valentina Bambini, Pier Marco Bertinetto, Det Danske Sprog- og Litteraturselskab, Esteban Fredin, Jeremy Goslin, Hannie van Hooff, Emmanuel Keuleers, MINDLab Project Initiation Peer Circle/Aarhus Universitet, Karl Møller, Michael Nygaard Pedersen, Cristina Romani, Donald Smith, Camilla Søballe Horslund, David Vernon, Philip Michael Zeman.

\section{Henvisninger}

Asmussen, J., et al. (red.) (2002). Korpus 2000. Dansk Sprog omkring årtusindeskiftet. København: Det Danske Sprog- og Litteraturselskab. http://korpus.dsl. $\mathrm{dk} / \mathrm{e}-$-resurser/adduser.php3?lang $=\mathrm{dk}$ (konsulteret maj 2012).

Bertinetto, P.M., et al. (red.) (2005). Corpus e Lessico di Frequenza dell'Italiano Scritto (CoLFIS). http://linguistica.sns.it/CoLFIS/CoLFIS_home.htm (konsulteret marts 2012).

Boersma, P. (2001). Praat, a system for doing phonetics by computer, Glot International 5(9/10), 341-345.

Carroll,J.B. (1981). Twenty-five years of research on foreign language aptitude, i K.C. Diller (red.) Individual Differences and Universals in Language Learning Aptitude, Rowley, Mass.: Newbury House, 83-118.

Dörnyei, Z. (2006). Individual differences in second language acquisition, AILA Review 19, 42-68.

Goslin, J., C. Galluzzi \& C. Romani (red.) (2013). PhonItalia: a phonological lexicon for Italian, Behavior Research Methods. Tilgængelig online: 10.3758/ s13428-013-0400-8; phonitalia.org_(konsulteret maj 2012).

Grigorenko, E.L., R.J. Sternberg \& M.E. Ehrman (2000). A Theory-Based Approach to the Measurement of Foreign Language Learning Ability: The Canal-F Theory and Test, The Modern Language fournal 84(iii), 390-405. Haarmann, H.J. \& K.A. Cameron (2005). Active maintenance of sentence 
meaning in working memory: Evidence from EEG coherences, International Fournal of Psychophysiology 57(2), 115-128.

Keuleers, E. \& M. Brysbaert (2010). Wuggy: A multilingual pseudoword generator, Behavior Research Methods 42(3), 627-633. http://crr.ugent.be/ programs-data/wuggy (konsulteret maj 2012).

Klimesch, W. (1999). EEG alpha and theta oscillations reflect cognitive and memory performance: a review and analysis, Brain Research Reviewes 29, 169-195.

Mårtensson, J. \& M. Löwdén (2011). Do intensive studies of a foreign language improve associative memory performance?, Frontiers in Psychology 2(12), 1-12. 